\title{
The Preservation of Samin Community Local Wisdom in Indonesia
}

\author{
Eny Kusdarini ${ }^{1}$, Alil Rinenggo ${ }^{2}$ \\ Yogyakarta State University, Indonesia ${ }^{1,2}$ \\ eny_kusdarini@uny.ac.id ${ }^{1}$,rinenggoalil@gmail.com²
}

\begin{abstract}
The local wisdom of Samin community in Indonesia which includes moral teachings and local traditions can be found in in Klopoduwur, Blora Regency. Along with the era development, the local wisdom of the Samin community begins to fade, especially within the younger generation of Samin. This research aims to describe the role of the elders, families, communities, and government in preserving Samin's local wisdom. The research employs a qualitative approach utilizing a realist ethnographic research design. The data were collected using some techniques which include in-depth interviews, documentations, and participatory observations. The data were validated by utilizing source and technique triangulation. The results show that the elders give advice to the Samin community members. The family plays an important role in educating children to live in harmony and uphold honesty and the values of mutual cooperation based on the local wisdom values of the Samin community. The Blora Regency Government has issued Regional Regulations pertaining to the use of Samin traditional clothes and organize an event of "Temu Ageng Sedulur Sikep Samin".
\end{abstract}

Keywords: preservation, local wisdom, the Samin community

\section{Introduction}

The government has acknowledged indigenous peoples to respect the cultural assets and uniqueness that are still preserved in various parts of Indonesia. This acknowledgement is also regulated in article $18 \mathrm{~B}$ paragraph 2 of the 1945 Constitution as a constitutional basis. Before the independence of the Republic of Indonesia, indigenous peoples had a system of values, beliefs or religion, and norms that were upheld to regulate family and community life in achieving social solidarity. Even, the indigenous peoples contibute to the state of life system by performing resistance to the Dutch colonial in Indonesia. The government highly respects the dynamics of the changing times that are eroding local culture, especially indigenous peoples.

Stavenhagen explains that indigenous peoples are included as non-dominant sector of society and have the willpower to preserve, develop and transmit ancestral territories and their ethnic identities for future generations as a basis for their sustained existence in a nation. The concept of indigenous peoples contains indigenous knowledge in it [1]. Everts defines indigenous knowledge as local knowledge that is unique for a particular culture or society. Indigenous knowledge aims to promote the values of personal, relational, and collective wellbeing because it identifies assets, especially in terms of knowledge owned by the community [2].

Along with the times or modernization, it is undeniable that the values of local wisdom or community culture as their identity are increasingly degraded [3]. This is proven by many local wisdom values that are no longer practiced in indigenous communities in Indonesia, for 
example; the value of togetherness, mutual cooperation, and natural resource management. The shift in social values of local wisdom can be seen from the degradation of values which have been accepted by the community and practiced by community members together [4].

The Samin community is an indigenous community established during the Dutch colonial period in Indonesia. The emergence of the Samin community began with the farmer's resistance movement against the Dutch government. This movement was pioneered by Samin Surosentiko or known as Raden Kohar. In 1890, Samin Surosentiko began to spread the teachings of Samin in Klopoduwur Village, Banjarejo District, Blora Regency, Indonesia [5]. Samin's teachings received a good response and attracted the attention of the surrounding villagers. Initially, the Samin Surosentiko movement did not pose a problem for the Dutch government, but in 1905, Samin's followers began to stay away from the public life in the village and refused to make donations to the village's granary [6].

The Samin's followers have spiritual teachings as a form of disappointment to the colonial and as a guide of life. The moral teachings of Samin's ancestors are still well preserved by Samin's followers. They can survive with simple life conditions and simple actualization in various fields of life till the present time. Moral values are set as the principle of life for adults of the Samin followers in Klopoduwur Village. The preservation of Samin local wisdom still lacks a full support from the village officials. This can be seen when the Samin community conduct a certain event, the village officials rarely come to join the event. One of the factors influencing this disharmony relationship is the negative stigma towards the Samin community.

Social institutions in social life play a very important role in fostering harmonization, progress and preservation of local culture. First, family is the most basic institution in transmitting values to children in order to instill morals based on the local culture. Second, the community is an inseparable part of the social environment in which norms are mutually agreed upon. Third, the government has the authority to take part in developing and advancing regions in accordance with the potential and characteristics of the region. Some of these social institutions must work together to preserve local wisdom as a national cultural identity with the uniqueness they have.

This research aims at describing the role of indigenous elders, families, Samin community, and the government in preserving Samin's local wisdom in Klopoduwur Village, Blora Regency, Indonesia. The role of stakeholders is expected to strengthen the identity of local wisdom which has noble values as assets and identity of the Indonesian people.

\section{Method}

This research is a descriptive research employing a qualitative approach of realist ethnography. Ethnographic design is a qualitative design that describes and interprets the shared and learned values, behavior, beliefs, and languages of a cultural group [7]. The researchers examine local wisdom in the form of noble values and traditions of the Samin community which are preserved by the Samin community and the government.The research data were validated through sources and techniques triangulation by comparing the results of interviews between research subjects to obtain the valid data. In addition, researchers validated data between interviews, observations, and documentation to strengthen research findings about the role of family, community, and government (village, district, and center) in the preservation of the Samin community local wisdom. An inductive data analysis was carried out in this research. In this case, the data (specific facts or events) were collected from 
the field, generalized, and then the conclusions were drawn based on the data collection techniques used. The data analysis employs six stages namely, organizing the data, reading data, coding data, linking themes, interpreting themes, and validating data accuracy.

\section{Results and discussions}

\subsection{The Role of the Samin's Elders and Family in the Preservation of Samin's Local Wisdom}

The local wisdom of the Samin community is in the form of moral teaching inherited by their ancestors in Klopoduwur Village named Mbah Engkrek. Local values include mutual cooperation, harmony, tolerance, honesty, and brotherhood. The elder acts as a giver of advice and reminds the public about the teachings of goodness. Samin elders remind members of the Samin community when their behavior or attitude violates the teachings of Samin. He never forces anyone but remind the Samin community members. The activity is usually carried out in the Samin village hall, a gathering place for Samin community members to get moral teachings from the Samin elders. Giving advice usually carried out after conducting joint prayers every Tuesday or Friday night of Kliwon (The names of the days of the week in Javanese) which takes place in the middle of rice fields or often referred to as "Dalan prapatan".

Sandlund says that giving advice means conveying messages to other parties, what is believed by the first party will be beneficial to the second party regarding attitude or behavior [8]. According to Vehvilainen, the order in which suggestions are given is part of the interaction where 'suggestions or advice should be followed by the receivers' [9]. By giving advice to someone, the giver also treats himself as someone who is more knowledgeable than the receivers [10].

The common life principles of the Samin community offer a positive impact on the security conditions in the Klopoduwur Village environment. So far, there has never been any theft in the Samin community. The teak tree owned by Forestry Office at the Samin village looks very big and intact without being stolen by the local community. This indicates that the Samin community members uphold the values of honesty. In addition, the Samin elder also act as mediators and provide advise to relatives when conflicts occur in the family.

The Samin elder is more wise and kind when facing problems in the family. The role of the Samin elder in this case is to make the community aware that fighting will not bring any benefits but it may cause dispute. All problems must have a solution and need to be solved together. According to the Samin elders, understanding each other is required in life. Harmony is preferred in addressing any issues and people should always perform mutual assistance in social activities in the community.

Family is an informal institution which has a great responsibility in performing moral education and teaching children as the next generation. Samin's family plays an important role by providing advice to children in their daily lives. The advice given to the children aims to instill the value of honesty and harmony. Honest refers to not taking property of others and getting along means not fighting to others both at home and at school. This advice is given when children want to go to school or when they play with their friends.

Education that takes place in the Samin's family is carried out democratically. Parents never give punishment, but they give advise children gently. Samin people view that parents 
are a manifestation of God in the world. All words and advice from parents must be respected by children. Respecting parents is always instilled from an early age. This value is taught to children when entering third grade of Elementary School.

Tafricha et al. explain that parents in Sedulur Sikep (Samin in Blora) instill moral values to children by employing an exemplary and habituation approach. The socialization applied in instilling the moral values to children in the Samin family tends to be flexible such as authoritarian, permissive, and democratic. The family members who play an important role in instilling moral values in the Samin's family in Klopoduwur Village are mother and father [11].

Samin's family has encouraged their children to go to formal education. They view that education is very important for children's lives. Most of the Samin's family was not well educated, so they encourage their children to go to school in order to be smarter than their parents and have friends everywhere.

The Samin community also introduces traditional games to their children to instill moral values. This traditional game is called "Pasaran", a game that is played by means of cooking exercises using natural ingredients, such as: soil, leaves, and water. This game aims to instill the value of mutual cooperation, collaboration, and harmony. These values will indirectly be integrated through the game. This game is played by children during the free time in the afternoon with peers. They look enthusiastic and happy when playing this traditional game.

Parents in the Samin family play an important role in educating children. Every morning at 05.30 a.m, parents give advice to their children to make preparations before going to school. Then, they are asked to have breakfast. After that, the children shake hands with both parents to go to school. Parents suggest their children to study hard and not to fight with friends.

Samin's family member whose role is to teach Samin's moral values is father and mother. They always advise children about harmony, brotherhood, and honesty. Beside giving advice, Samin's family members also employ the exemplary method when educating their children by speaking good words (polite), performing simple life and getting along with anyone. Moral education conducted by the Samin family has a positive impact on children's development. For example, children are always obedient to parents.

Dewantara explains that family is a better place for education when viewed from its nature and model compared to other institutions. Education carried out in the family aims to improve the moral intelligence or the formation of individual character to enhance social life [12]. In the family, parents can internalize the values or instill the spiritual values to children. Parents in the family can act as teachers (moral leaders), become educators (provide knowledge or intelligence leaders) and be an example / role model for social behavior [13]

The Samin's community also has a great role and responsibility in internalizing the moral values to preserve the local wisdom. The efforts performed by the community members include conducting a gathering and sharing on the Samin's teaching in the elder's house and hall. The hall was provided by the Central Java Provincial Government in 2010 as a place to gather the fellow members or followers of Samin's teachings. The gatherings/meetings among Samin's followers are held every night on Tuesday and Friday of Kliwon (The names of the days of the week in Javanese). This activity contributes to develop mind and heart of the Samin community members in order to understand and inspire Samin's moral values. The role of the Samin community in the preservation of local wisdom is supporting social activities in achieving the common goodness which include realizing harmony, mutual cooperation, brotherhood, and tolerance between religious communities.

The Samin community in Klopoduwur views that the values must be passed down from generation to generation in order to preserve them. The sense of belonging to the Samin 
culture is one of the factors that encourage Samin's community to implement and enhance the preservation of local wisdom. The Samin community strongly supports the implementation of Samin's moral values in Klopoduwur Village. They believe that Samin's teachings do not conflict with any faith or religion. Communities coexist without a conflict of interest. The existence of the "Sedulur Sikep Samin" community allows people at Klopoduwur Village to easily get support from the government, for example: water assistance, house renovation, livestock, and other supports.

The Samin community members are responsive towards social activities in Klopoduwur Village. They will attend and participate in the social activities without being noticed. They are directly involved in various activities in the community, for example: gathering in the hall, Quran reading gathering, and mutual cooperation to build houses or village roads. According to Soekanto, social institutions are guidelines in behaving and acting, maintaining the integrity of the community, and performing social control over the behavior of its members [14].

The educational process is continuously running in a civilized society. Education facilitates a cultural transmission in which it enhances the development of good morals, which include: religious, skilled, responsible, and intact human being [15]. The role of the Samin community in the preservation of local wisdom is enhancing social activities to achieve the common goodness, namely creating harmony, carrying out mutual cooperation, enhancing brotherhood, and performing tolerance between religious communities to realize national unity. The preservation of local wisdom will not run well without the support from each member of the Samin's family. The Samin community in Klopoduwur is very enthusiastic and believes that the ancestral values must be inherited from generation to generation to sustain them. The sense of belonging becomes one of the factors that encourage the community to keep implementing and supporting the preservation of the local wisdom. According to Cross, et al., indigenous or local knowledge is a collection of cumulative knowledge, practices, and beliefs. It develops through adaptive processes and is handed down to generations through cultural transmission, concerning the relationship with living things and with their environment [16].

Ki Hadjar Dewantara states that a good coordination in the three education centers such as the family, schools, and community is required, so that they can complement each other's weaknesses. They must establish cooperation in planning, implementing and institutionalizing education [17]. Based on the theory of Ki Hajar Dewantara, the preservation of local wisdom of the Samin community has become a shared responsibility of the Samin elders, the Samin family, and the community in Klopoduwur Village. They jointly develop moral values such as harmony, brotherhood, tolerance, honesty, and peace as part of the local wisdom of the Samin community.

\subsection{The Role of the Village Government, Blora Regency, and the Central Government in the Preservation of Samin's Local Wisdom}

The Klopoduwur Village Government supports the preservation of local wisdom carried out by the Samin elders. The reinforcement is only limited to providing freedom to the Samin's community to teach based on their beliefs, but there are no concrete steps to advance the culture of the Samin community. The village chief of Klopoduwur had previously established Tourism Awareness Group to introduce the culture of Samin to the community, but it had not been running well viewed from its management.

The regional government through the Deputy Regent of Blora Regency, Arief Rohman, was pleased and thanked the Indonesian Ministry of Education and Culture for establishing 
Samin culture as an intangible cultural heritage. The regional government hopes to establish Blora as a city of Culture [18]. Furthermore, the Head of Youth, Sports, Culture and Tourism Office in Blora Regency fully supports the preservation of the local wisdom values of the Samin community. This was proven by organizing a program of "Cerita dari Blora" which promoted the culture of Sedulur Sikep (Samin Community). The program was coducted on September 19-22, 2019 in collaboration between the Blora Regency Government and the Ministry of Education and Culture. A series of festival also promotes local wisdom in Blora Regency [19]. On the first day, the event of "Temu Ageng Sedulur Sikep Samin" was held. It was intended to strengthen the Sedulur Sikep (followers of Samin's teachings) brotherhood and to confirm the teachings of Samin Surosentiko which were spread in various regencies, Central and East Java Samin community leaders who attended the event were Pramugi, Poso, Mbah Lasiyo (from Klopoduwur, Blora), Gunretno and Gunarti (from Pati), Bambang Sutrisno (from Bojonegoro), and Budi Santoso (from Kudus) [20]. This is part of the support given by the Blora District Government by inviting Samin elders to attend the festival of "Cerita dari Blora".

The Blora Regency Government always provides opportunity for the Samin community members to take part in the Indonesian independence day celebration and provides a financial support for the Samin community activities. This will encourage the preservation of local wisdom which exists in the Samin community. The government realizes that Samin culture is so a potential that it must be maintained or preserved. The universal values of local wisdom such as harmony, honesty, and brotherhood should be realized both within the community and the government institutions. The Blora Regency Government is trying to preserve Samin's cultural values by instructing the civil servants to wear black clothes every 15 th that reflect the Samin culture. Samin's black traditional cloth means simplicity. It is expected that Civil Servants in the Blora Regency would perform a simple and honest attitude in serving the community members.

The use of Samin's traditional cloth by civil servants in the Blora Regency is stipulated by the Regent's Regulation No. 28 of 2017 concerning the changes to the Blora Regent's Regulation No. 46 of 2016 concerning office uniform for civil servants within the Blora Regency Government [21]. In article 2 paragraph (1), letter (a) number 5, it is stated that the daily service uniform of Samin is included as one of the office uniform for civil servant in Blora Regency. This Regent's Regulation indicates that the Blora Regency Government highly support and intend to preserve the culture of Samin. In addition, the wall of the living room in the Youth, Sport, Culture and Tourism Office of Blora Regency is decorated with a picture that displays the legendary figure of the Samin community, namely Samin Surosentiko. This is also one of the efforts to commemorate and appreciate Samin Surosentiko's services against the Dutch government. According to Jang, indigenous cultural communities, viewed from the government perspective, cannot grow abstractly but it must be developed through various institutional contexts and is directed to meet contextually determined goals [22]. In this context, the Blora Regency government has tried to maximize the potential that exists in the Samin community to become a typical culture of Blora Regency.

The government has an obligation to maintain the regional culture as a national cultural asset. President Joko Widodo and his entourage visited the Samin Blora community in 2015 proven by a photo of President Joko Widodo with the Samin community members. This shows the appreciation of the central government for the preservation of Samin culture. The President of Joko Widodo advised the Samin community to preserve and sustain the values of local wisdom inherited by their ancestors. By caring for and fostering the local culture, we also care for the national culture. 
The efforts to preserve the Samin culture are strongly supported by the central government. This support was given to the followers of the Samin Blora teachings which are acknowledged with a certificate issued by the Minister of Education and Culture of The Republic of Indonesia Number 65682 / MPK.E / KB / 2018. The certificate shows a recognition of the central government on the values of local wisdom that have been used as guidelines or principles of life by the Samin community members. The appreciation given by the central government motivated the Blora District Government to explore Blora's native culture as a culture-based regional development.

The head of the Youth, Sport, Culture and Tourism Office of Blora Regency states that the local wisdom of the Samin community is recognized as an intangible cultural heritage by the central government. With this acknowledgment, the people of Klopoduwur Village and Blora Regency Government will benefit materially and non-materially. A positive impact of this recognition is encouraging the preservation of Samin's moral and cultural teachings. Based on article 18 B paragraph 2 of the 1945 Constitution, the state acknowledges and respects the customary law community units along with their traditional rights as long as they are still alive and in accordance with the development of society and the principles of the Unitary State of the Republic of Indonesia, which is regulated by law. The article gives constitutional position to the customary law community and becomes a constitutional basis for the state administrators, therefore the government should treat the customary law community as it is [23]. The preservation of Samin culture is strengthened by the existing components in the community, namely the Samin elders, families, and the Samin community in Klopoduwur Village. The preservation of local wisdom can be sustained if it is performed by utilizing the local strength and the self power. This requires contribution of the lovers, observers, and supporters from various parties. The community needs to develop strong motivation, take action and participate in preserving local wisdom [24].

\section{Conclusion}

One of the local wisdoms of the Samin community is moral teachings which includes the value of mutual cooperation, harmony, brotherhood, tolerance, and honesty. These local values have become a characteristic that is taught and practiced in everyday life in the Samin community in Klopoduwur Village. The synergy between the Samin indigenous elders, family, community, and the government may sustain Samin culture amidst the advancement of the modern era. The elder is preceived as a respected person by the followers of Samin's teachings. The followers of these teachings indirectly actualize the moral teachings of Samin in their family. From the structure of each Samin family, a community is establised as a social community that has a vision to uphold mutual cooperation, honesty, tolerance, brotherhood, and harmony. The preservation of local wisdom is also reinforced by the regional and central government by promoting Samin culture as an intangible cultural heritage.

\section{Acknowledgements}

The authors would like to thank the Directorate of Research and Community Service, Deputy of Strengthening Research and Development of the Ministry of Research and 
Technology / National Research and Innovation Agency for funding master thesis research according to the 2020 budget research contract, number: 058/SP2H/LT/DRPM/2020.

\section{References}

[1] R. Stavenhagen, Pioneer on indigenous right. New York: Springer, 2013.

[2] E. H. Everts, "Integrating indigenous knowledge in education and healthcare in Northern Malawi : Pregnancy through Toddlerhood," 2013.

[3] A. Ufie, "Mengonstruksi nilai-nilai kearifan lokal (local wisdom) dalam pembelajaran muatan lokal sebagai upaya memperkokoh kohesi sosial (studi deskriptif budaya Niolilieta masyarakat adat Pulau Wetang Kabupaten Maluku Barat Daya, Propinsi Maluku)," J. Pendidik. dan Pembelajaran, vol. 23, no. 2, pp. 079-089, 2016, [Online]. Available:

http://journal.um.ac.id/index.php/pendidikan-dan-pembelajaran/article/view/10157.

[4] D. Hidayati, "Memudarnya nilai kearifan lokal masyarakat dalam pengelolaan sumber daya air," J. Kependud. Indones., vol. 11, no. 1, p. 39, 2017, doi: 10.14203/jki.v11i1.36.

[5] M. Rosyid, "Studi komparatif konsep ketuhanan Islam dan agama Adam pada komunitas Samin," J. Stud. Keislam., vol. 16, no. 2, pp. 403-442, 2012.

[6] I. Pinasti and T. Irenewaty, "Kajian historisitas masyarakat Samin Di Blora dalam perspektif pendidikan karakter," Pros. Semin. Nas. "Meneguhkan Peran Penelit. dan Pengabdi. Kpd. Masy. dalam Memuliakan Martabat Manusia” pada, pp. 449-459, 2016.

[7] J. W. Creswell and C. N. Poth, Qualitative inquiry \& research design choosing among five approaches fourth edition, vol. 53, no. 9. Thousand Oaks, California: SAGE Publications, Inc, 2018.

[8] E. Sandlund, "Prescribing conduct: enactments of talk or thought in advice-giving sequences," Discourse Stud., vol. 16, no. 5, pp. 645-666, 2014, doi: 10.1177/1461445614539065.

[9] S. Vehviläinen, "Student-initiated advice in academic supervision," Res. Lang. Soc. Interact., vol. 42, no. 2, pp. 163-190, 2009, doi: 10.1080/08351810902864560.

[10] C. Shaw and A. Hepburn, "Managing the moral implications of advice in informal interaction," Res. Lang. Soc. Interact., vol. 46, no. 4, pp. 344-362, 2013, doi: 10.1080/08351813.2013.839095.

[11] A. N. Tafricha, Suprayogi, and A. Suhardiyanto, "Penanaman nilai-moral anak dalam keluarga Samin (Sedulur Sikep) Kabupaten Blora," Unnes Civ. Educ. J., vol. 1, no. 2, 2013.

[12] K. H. Dewantara, Bagian pertama pendidikan. Yogyakarta: Yayasan Persatuan Tamansiswa, 2011.

[13] H. Suparlan, "Filsafat pendidikan Ki Hadjar Dewantara dan sumbangannya bagi pendidikan Indonesia," J. Filsafat, vol. 25, no. 1, p. 56, 2015, doi: 10.22146/jf.12614.

[14] Soekanto, Sosiologi pengantar. Jakarta: CV Rajawali, 2006.

[15] H. A. R. Tilaar and R. Nugroho, Kebijakan pendidikan: pengantar untuk memahami kebijakan pendidikan dan kebijakan pendidikan sebagai kebijakan publik. Yogyakarta: Pustaka Pelajar, 2009.

[16] Cross et al., "Guidance for integrating indigenous and local knowledge (IKL) in IUCN red list assessments.," IUCN CEESP/SSC Sustain. Use Livelihoods Spec. Gr., no. November 2017, 2017, doi: 10.13140/RG.2.2.29611.49446.

[17] C. Agus, P. A. B. Cahyanti, B. Widodo, Y. Yulia, and S. Rochmiyati, "Cultural-based education of Tamansiswa as a locomotive of Indonesian education system," World Sustain. Ser., pp. 471486, 2020, doi: 10.1007/978-3-030-15604-6_29.

[18] T. L. H. P. Setda Blora, "Sedulur Sikep (Samin) Blora ditetapkan Kemdikbud RI sebagai warisan budaya tak benda," 2019. Accessed: Aug. 07, 2020. [Online]. Available: https://setda.blorakab.go.id/post/114/sedulur_sikep_(samin)_blora_ditetapkan_kemdikbud_ri_se bagai_warisan_budaya_.

[19] T. Budi, "Indonesiana cerita dari Blora angkat budaya Samin." Accessed: Aug. 07, 2020. 
[Online]. Available: https://daerah.sindonews.com/artikel/jateng/8475/indonesiana-cerita-dariblora-angkat-budaya-samin.

[20] A. Muiz, "Mencocokkan ajaran Samin dalam kehidupan - Suaramerdeka." Accessed: Aug. 07, 2020. [Online]. Available: https://www.suaramerdeka.com/smcetak/baca/199532/mencocokkanajaran-samin-dalam-kehidupan.

[21] B. Sukarno, Peraturan Bupati Nomor 28 Tahun 2017 tentang Perubahan atas Peraturan Bupati Blora Nomor 46 Tahun 2016 tentang Pakaian Dinas bagi Pegawai Negeri Sipil di Lingkungan Pemerintah Kabupaten Blora. 2017.

[22] H. S. Jang, Social identities of young indigenous people in contemporary Australia: Neocolonial north, Yarrabah. Switzerland: Springer International Publishing, 2015.

[23] Muazzin, "Hak masyarakat adat (indigenous peoples) atas sumber daya alam: perspektif hukum internasional," PADJADJARAN J. Ilmu Huk. (Journal Law), vol. 1, no. 2, pp. 322-345, 2014, doi: $10.22304 /$ pjih.v1n2.a7.

[24] A. Karmadi, "Budaya lokal sebagai warisan budaya dan upaya pelestariannya," Makal. disampaikan pada Dialog ..., pp. 1-6, 2007, [Online]. Available: http://repositori.kemdikbud.go.id/1063/ 